\title{
What A Dog Fight! TKO: Pets.com
}

Erika Matulich, University of Tampa

Karen Squires, University of Tampa

\begin{abstract}
The case covers the startup of Pets.com, an online retailer of pet supplies. Pets.com made its entry into a heavily competitive but potentially lucrative market. Despite heavy capital funding and a number of high-profile strategic initiatives, the company closed its doors in November, 2000. The demise of Pets.com is considered to be one of the highest-profile dotcom failures.
\end{abstract}

Keywords: SWOT analysis, pro forma financial statements, IPO, initial public offering, strategic analysis.

\section{BIRTH OF A BUSINESS}

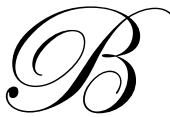

ack in 1994, Greg McLemore, a 31-year old California entrepreneur, registered the Pets.com web address and launched an online community for pet owners. The site lingered on until its potential was noticed by several entrepreneurs and investors. By 1998, Pets.com added e-commerce capabilities and brought web-veteran Julie Wainright to the helm. Her first act was to offer a 50-percent stake in the business to the formidable Amazon.com. Jeff Bezos, Amazon's CEO, who took the opportunity in his effort to move from books, videos, and CDs into offering consumers "anything they might want to find online." Along with Amazon, blue-chip venture capitalists Hummer Winblad Partners, Bowman Capital, and Catalyst Investments LLC raised nearly \$110 million in four rounds of private-placement funding by December, 1999. This capital allowed Pets.com to invest in the necessary hardware and human resources to run a true e-commerce site.

At this time, Julie Wainright put the new mission statement on the website:

"Pets.com is committed to serving pets and their owners with the best care possible through, products, information, and service. Pets.com is an online retailer of pet products, information, and resources. Offering a broad product selection and expert advise from a staff of pet-industry experts and veterinarians, Pets.com believes that it gives consumers the confidence that they are providing their pets with the best possible care."

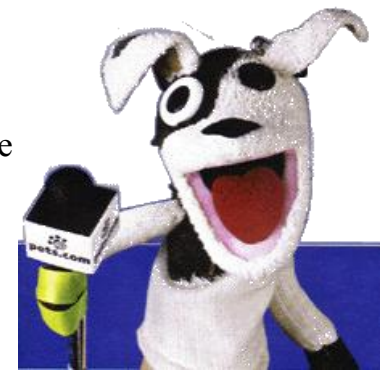

\section{A COMPETITIVE RACE}

Amazon's stake in Pets.com directly challenged the leaders in the brick-and-mortar retail pet industry (those with physical stores). In response to the online threat of Pets.com, PetSmart immediately launched its petstore website to compete with the already existing dot-com independents Petstore.com and Petopia.com (later bought by Petco). Pets.com's Ms. Wainright continued her high-powered strategy by luring executives from Procter \& Gamble and Petco and beginning a high-visibility television campaign that ranked seventh among all e-commerce companies in advertising volume and first by far among all the Internet pet stores for the 1999 holiday season. ii Pets.com was the first dot-com company in the Macy's Thanksgiving Day Parade, which featured the famous sock-dog "spokespuppet." The company also spent an estimated \$2.2 million to feature the sock puppet in the 2000 Super Bowl XXXIV advertising event (the ad was voted the fifth most popular spot). ${ }^{\text {iii }}$ The puppet used in the ad later was auctioned for $\$ 20,100$ on Amazon.com. 


\section{THE PET SUPPLY MARKET}

Why all the fuss about selling pet supplies online? Almost two-thirds of all American households have at least one pet, and that translates into an estimated $\$ 23$ billion a year in pet expenditures in the U.S. alone. Worldwide estimates run about $\$ 51$ billion, and growing at a rate of about 15 percent a year. By the end of 2004, online pet-product sales alone should total more than $\$ 4.5$ billion. $^{\text {iv }}$ Pets.com targets time-strapped pet owners with its slogan, "because pets can't drive." In this potentially lucrative growth market, the stakes are high and the competition is hot.

\section{PETS.COM STRIVES FOR DIFFERENTIATION}

In this highly competitive market, Ms.Wainright and Pets.com executives took several strategic initiatives in an effort to stand out. First, it strived to offer a huge variety of product offerings for cats, dogs, ferrets, fish, reptiles, and small animals; in fact it listed more SKUs than any other online pet supplier. It was the only one of the online pet product sites to have separate offerings for ferrets, the third most popular companion mammal in America. Pets.com also offered abundant editorial advice from veterinarians, animal lawyers, breeders, scientists, and pet experts. The advice and information was updated and added to on a weekly basis. The masses of information were efficiently managed and made accessible through the "Ask-o-matic" intelligent search engine. Pets.com also extended its brand offline to the Pets.com print magazine, which dramatically increased its customer base to over a quarter of a million people. ${ }^{v}$

\section{IPO CASH ALLOWS FURTHER STRATEGIES}

At Julie Wainright's direction, Pets.com decided to start selling its stock to the general public in an initial public offering (IPO). The sale of stock is regulated by the Securities and Exchange Commission (SEC). Companies planning an IPO are required to file a Prospectus with the SEC. A Prospectus is a formal written document to sell securities that describes the plan for a proposed business enterprise, or the facts concerning an existing one, which a potential investor needs to make an informed decision. This information was published in the Pets.com IPO Prospectus, shown in Exhibit 1.

Exhibit 1

Pets.com

Selected Financial Data (from Prospectus)

(In Thousands)

\begin{tabular}{|c|c|c|c|}
\hline \multirow[b]{3}{*}{ Statement of Onerations (see note). } & \multicolumn{3}{|c|}{ Quarter Ended } \\
\hline & \multicolumn{2}{|c|}{ 30-Sep-99 } & \multirow{2}{*}{ 31-Dec-99 } \\
\hline & & & \\
\hline Net sales & $\$$ & 568 & $\$ 5,168$ \\
\hline Cost of goods sold & & 1,766 & 11,570 \\
\hline Gross margin & $\$$ & $(1,198)$ & $\$(6,402)$ \\
\hline Operating expenses: & & & \\
\hline Marketing and sales & $\$$ & 10,693 & 30,676 \\
\hline Product development & & 2,194 & $\$ 2,646$ \\
\hline General and administrative & & 1,205 & 2,211 \\
\hline Amortization of Stock-based compensation & & 1,139 & 979 \\
\hline Total operating expenses & & 15,231 & 36,512 \\
\hline Operating loss & & $(16,429)$ & $(42,914)$ \\
\hline Interest Income, net & & 577 & 491 \\
\hline Net loss & $\$$ & $(15,852)$ & $\$(42,423)$ \\
\hline
\end{tabular}

Note: the term "income statement" can only be used for the operating results of profitable companies. Because Pets.com has losses, it must use the term "Statement of Operations" instead. 
This cash flow allowed the company to develop and offer its own proprietary brand of Pets.com cat and dog foods, biscuits, and litter. The company also acquired Petstore.com, including its 100,000-name customer list, its Flying Fish Express live fish business, and its cross-promotional relationship with Discovery Communications (including TV cable channels Discovery and Animal Planet). ${ }^{\text {vi }}$ Several strategic alliances allowed Pets.com to offer animal health insurance, be the featured petstore on the Yahoo! link to pet health advice, be a part of the Go.com (Disney) network, and establish charitable foundations.

\section{TROUBLE IN PARADISE}

Despite these bold moves and strategic actions, the road to pet paradise was rocky. Initially, Pets.com only had one distribution warehouse in California, and offered a guaranteed $\$ 4.95$ shipping to anywhere in the United States. Every shipment to the East Coast cost more than $\$ 4.95$ and therefore shipped at a loss. The firm finally opened a warehouse near Indianapolis, Indiana, and began planning further distribution centers in strategic geographic locations. Shipping prices, although still low, were adjusted to better reflect actual costs.

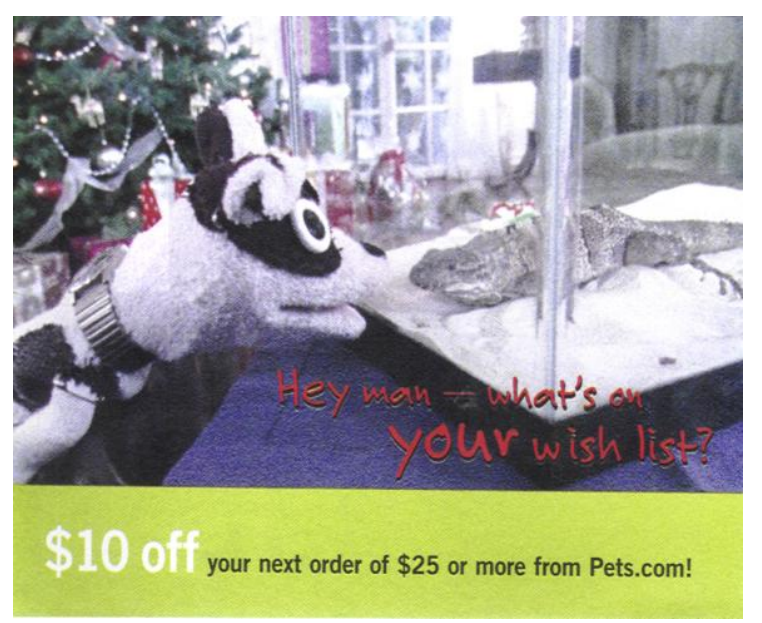

Many customers were lured to the site by offers of big sales, online coupons, and deep discounts. This action had the effect of slashing razor-thin profit levels - less than 2 percent, and as a result, some shipments went out below cost once again. Because of the high cost of goods sold, Pets.com stock (NASDAQ: IPET) plummeted from its initial $\$ 11$ to the low single digits. Customers were still confused about brands - Petopia received plenty of email about "that wonderful sock dog." And although Pets.com won numerous awards for best online pet site and best e-tailer in order fulfillment, it got less visitor traffic than Petsmart.com. Investors and consumers began betting on clicks-and-bricks (firms with both an online and physical store presence), rather than clicks-only, as the winning formula.

Despite these setbacks, Pets.com continued an aggressive growth strategy, planning to add horse products to the site to tap into yet another billion-dollar market. Sock puppet merchandising was a popular ploy of Pets.com in its quest to be best in the lucrative pet product marketplace. And interestingly, the poor stock performance of Pets.com prevented other pet sites from doing their IPOs or generating further venture capital, leaving competitors cash strapped and unable to grow.

\section{IN SPITE OF IT ALL...}

In the end, not even the famous Sock Puppet could prevent Pets.com from becoming one of the first publicly traded Internet companies to fall. On November 7, 2000, Julie Wainright announced layoffs of most employees, and put the Pets.com assets up for sale. Company executives had debated on whether to continue through the potentially profitable holiday season, and had enough cash to last through April, 2001. However, CEO Julie Wainwright believed that the company should be responsible to its vendors, employees, and shareholders, and chose not to declare bankruptcy and instead settle all its accounts.

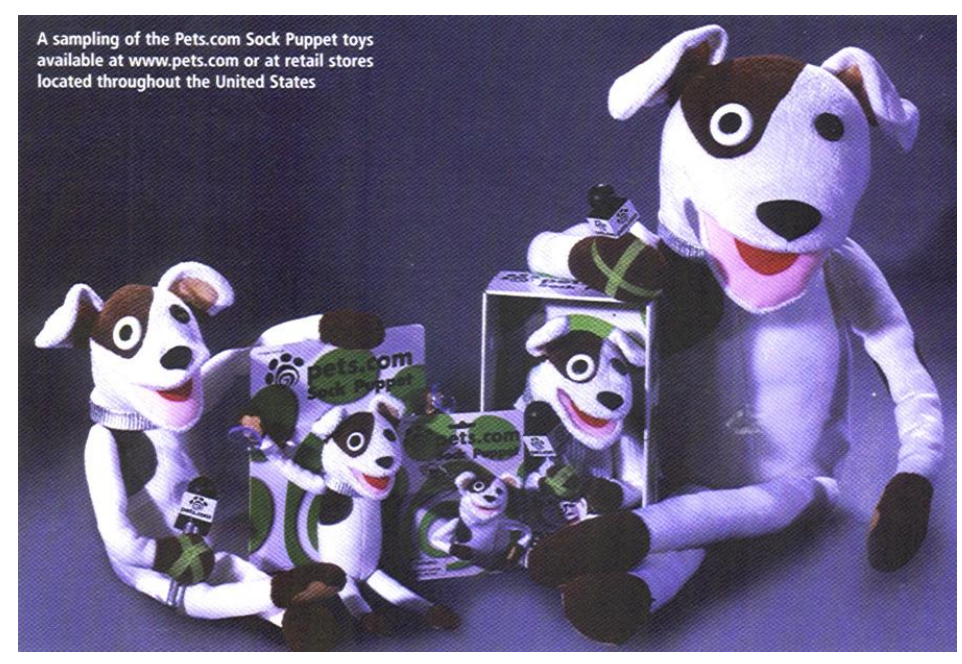


This decision was largely due to a need for an extra capital infusion of $\$ 20$ to $\$ 30$ million in funding, and the lack of interested capital funding prospects.

As the dot-coms continued to crash through the end of 2000, few companies were interested in putting even more money into Pets.com. Of the 50 domestic and international prospects contacted for buying or merging with Pets.com to provide the extra cash needed, fewer than eight were prepared to visit with the company. Although an internal business plan showed that Pets.com would be profitable by 2002, the marketplace fears and short-term views on return made the fundraising impossible. ${ }^{\text {vii }}$

By early 2001, extra inventory had been returned to suppliers or sold at deep discount to the Tuesday Morning outlet stores. Intellectual property, including the website url, all editorial and informational content, artwork, and the Sock Puppet, were sold to Petsmart. The url and customer list was perhaps the most valuable asset of all - with over half a million loyal customers, more than any other online pet supply retailer at the time, Petsmart made a wise buy.

\section{CONCLUSION}

Pets.com has been one of the highest-profile dot-com failures. It underscores how business-to-consumer Internet sites are struggling to find sustainable business models, even with massive infusions of capital, dwindling competition and national ads that grabbed the public's imagination. Matt Stamski, a senior analyst at Gomez Advisors, commented on the closure of Pets.com as well as rival pet-supply Web sites. "It's almost unprecedented to see an entire sector go from an idea to heavily funded to defunct in just a year and a half." viii

\section{DISCUSSION QUESTIONS}

1. Evaluate the mission statement of Pets.com.

2. What measurable marketing objectives should Pets.com have set for their company?

3. Perform a brief SWOT analysis.

4. What sustainable competitive or differential advantages should Pets.com have capitalized on?

5. Who was Pets.com targeting? What segmentation principles should be applied to such a target market?

6. Briefly identify and describe the marketing mix elements for Pets.com, including product, place, promotion, and price.

7. How did evaluation and control play a part in Pets.com strategic planning efforts?

8. Was the short-term profit orientation of potential investors the key reason for Pets.com's demise?

9. Prepare a vertical analysis of the December 30, 1999 quarterly statement. Introductory classes will need instructions as to how to do the calculations (divide every number in the column by Net Sales).

10. Will increasing sales improve Pets.com's financial performance? Based upon the vertical analysis, if Pets.com was successful in expanding sales, what would the Statement of Operations look like if Pets.com sales grew from $\$ 5.168$ million in the fourth quarter of 1999 to $\$ 10$ million?

\section{ACTIVITIES}

1. How many of your friends own pets? Ask the pet owners whether any of them order pet supplies online or belong to a food subscription service. Why or Why Not? How do they purchase their food and supplies?

2. Go online and attempt to order Totally Ferret Food. How easy was this to find? Were there price differences among vendors?

3. Choose a specialty pet market, such as horses, ferrets, tropical fish, iguanas, etc. Which online retailer has the best site tailored to the needs and wants of this specific market?

4. Take on the role of a venture capitalist. If you had $\$ 50$ million to invest in Pets.com to prevent its closure, would you invest? Why or Why Not? 


\section{DECISION-MAKING QUESTIONS}

1. If you were Julie Wainright, would you have tried to sell Pets.com to PetSmart or PetCo? If so, at what point?

2. From PetSmart's point of view, would Pets.com be a good company to purchase? At what price? How should Pets.com's assets be valued?

3. At what stage of the business should Julie Wainright have decided to have multiple distribution points? How many distribution warehouses should there have been?

4. From a promotional point of view, when would you have stopped the "introductory pricing" that led to the high cost of goods sold?

5. What would an appropriate product mix be for an online retailer of pet products with no brick-and-mortar counterpart?

Teaching Note/Instructor Manual is available from the authors.

\section{REFERENCES/ENDNOTES}

i Brad Stone, Amazon's Pet Projects, Newsweek, June 21, 1999 (Volume 123 Issue 25), p. 56.

ii Leslie Kaufman with Saul Hansell, Holiday Lessons in Online Retailing, New York Times, Jan 2, 2000, Section 3 Page 3.

iii Mara Reinstein and Steve McClellan, Super Bowl Spots Don’t Score, Broadcasting \& Cable, February 7, 2000 (Volume 130 Issue 6) p. 28.

iv Joel Enos, Vying to be the Top Dog, Upside, March 2000 (Volume 12 Issue 2), pp. 160-165.

v Charlie Fletcher, Pets.com Publishes Print Magazine, Catalog Age, June 2000 (Volume 17 Issue 7), p. 12.

${ }^{v i}$ Diane Rezendes Khirallah, Pets.com Swallows Rival, Informationweek, June 192000 (Issue 791) p. 18.

vii Tam, Pui-Wing and Mylene Mangalindan, Pets.com's Demise: Too Much Litter, Too Few Funds, The Wall Street Journal, November 8, 2000, p. B1+.

viii Tam, 2000. 


\section{NOTES}

